\title{
Geological and Archæological Aspects of South-Eastern Asia
}

\author{
By Dr. H. de Terra, P. Teilhard de Chardin and \\ Dr. Hallam L. Movius
}

$\mathrm{M}^{\mathrm{B}}$ EASURING the age of man in terms of cyclic geological processes has always been a subject fascinating to the student of the Ice Age. Unfortunately, too little is known of such processes outside the glaciated regions to work out a stratigraphic scheme which might be applied to wider regions, and yet this would be the solution to many important problems concerning the Quaternary and the prehistory of man. In Asia, for example, mammalian fossils enable us to distinguish roughly between three Quaternary divisions, but the fossil localities are scattered far and wide, and the Quaternary formations, traditionally passed over by governmental surveys, are very imperfectly known.

The wish to put our knowledge of the Ice Age in southern Asia on a geological basis led three years ago to the joint Yale-Cambridge Expedition to Kashmir and India, the results of which are now in process of publication by the Carnegie Institution of Washington. From these results, the Quaternary of India, was seen to have been determined by diastrophic and climatic events of a very distinct nature, permitting a detailed subdivision of the Ice Age. Its periodic character was expected to make this stratigraphic scheme applicable to neighbouring regions, or to supplement it by additional information. In this way, it was also hoped that the Cenozoic geology of India might become more clearly integrated with that of China, which in turn would aid in the study of Early Man. In discussing this plan with Father Teilhard de Chardin at the occasion of the symposium, held in March 1937 in Philadelphia, we planned to study the late Cenozoic geology and archæology of Burma. Burma, being favourably situated geographically between India and China, held out considerable promise, especially since Palæolithic tools had been found there recently by Mr. T. O. Morris, in association with terraces. A few salient features of the Quaternary of Burma will be briefly outlined below. Father Teilhard de Chardin co-operated with the expedition during the four months of field work, and the third author carried out the archæological work in close association with the geological party.

The expedition was undertaken under the joint auspices of the Academy of Natural Sciences of Philadelphia and the Peabody Museum of Harvard University. Following the field season in Burma, all members of the expedition proceeded to Java. There, during the month of April, we had the opportunity of visiting, under the expert guidance of Dr. von Koenigswald, the sites at which fossil man and Palæolithic implements had been discovered in recent years.

\section{TERRACE System of the IrRawaddy Valley}

In the Irrawaddy Valley our investigations were carried out chiefly between Magwe and Nyaungoo, near Pagan, but various excursions were made also along tributary streams leading westward to the Arakan Yoma Mountains. The most characteristic features of the Irrawaddy terraces are as follows :

(1) They are superimposed on the 'Irrawaddy Series', a folded and peneplained river formation, the upper part of which contains a mammal fauna analogous to that of the Upper Siwaliks of India.

(2) Occupying an old valley, the terraces are mainly composed of coarse boulder-bearing gravels in which three distinct stages of aggradation could be differentiated.

The highest terrace gravel is preserved in a group of hills, situated in the oilfield of Chauk, and some $350 \mathrm{ft}$. above the stream. The size of its pebbles depicts an ancestral Irrawaddy much more powerful than the present river. An oldest lateritic soil mantle in the adjoining hills appears to be connected with this stage, which clearly was a period of greater rainfall. (At present this region belongs to the 'dry belt' of Burma, with $60-70$ inches of annual rainfall which falls almost entirely between the months of June and September. No lateritic soils are formed here at present.) At one place the bighest terrace was found to contain some flaked pebbles of fossil wood and silicified tuff. This terrace is strongly tilted.

The second and third terraces lie some $180 \mathrm{ft}$. and $100 \mathrm{ft}$. respectively above river-level, and are associated with a thick series of red gravel and sand. In this was found near Mingun, opposite Mandalay, a Middle Pleistocene type of fauna (with Elephas namadicus), and farther downstream an Early Palæolithic industry (see under Archæo$\operatorname{logy}$ ). A long interval of erosion and of aridity preceded the deposition of this second river drift, and then a valley was formed with ferrugineous 
soil caps containing the earliest prehistoric industry. The second river gravel buried the valley, but prenistoric settlements continued, as indicated by the wealth of rolled Palæolithic tools in the basal gravels. Again this was a period of increased weathering and water supply, during which the adjoining highlands released thick fans of 'red earth' on to the second terrace.

The fourth terrace is made of the third type of gravel, which is generally less coarse and more sandy. A somewhat advanced type of Palæolithic was found in this. The fifth terrace $(25 \mathrm{ft}$.) approaches in composition the recent river deposit, and may be post-Pleistocene in age.

(3) The terraces are associated with soils corresponding to periods of greater and lesser rainfall. The first and second type of gravels are connected with lateritic soils, found on the adjoining land surface. From here 'red earth' was washed into the valley, especially during formation of the second terrace, in which fine-grained red sand merges laterally into lateritic slope-wash deposits. Increasing aridity is indicated by the presence of loessic soils on the fourth terrace. This soil is of yellow or pinkish colour, mostly structureless, and was drifted in the manner of true loess on top of the third terrace the erosional surface of which was thus again buried. The composition of this fourth terrace, however, proves that this must have been a major and prolonged fill stage.

(4) The Irrawaddy terrace system is of regional extent, for it was found also in the adjoining Shan Plateau in the reaches of the Namtu and Salween Rivers.

The interpretation of these features leads to conclusions which are of importance to both geologist and archæologist. It is interesting to note the great resemblance of this terrace system with that found in North-West India, both in respect to the number and the nature of the physiographic cycles. In both regions the terrace formation began in the Middle Pleistocene, because of the then established relative stability in the Himalayan foredeeps in which the Early Pleistocene beds are generally strongly folded. In India, three major fill stages could be correlated with the three last Himalayan glaciations, and terraces were ascertained some 150 miles distant from the limits of glaciation. In Burma, the distance from the glaciated tracts is more than double that amount, but here the soil records indicate the impact of corresponding climatic cycles in the nature of 'Pluvial' and 'Interpluvial' stages, which were apparently superimposed on cyclic diastrophic processes. It is probable that in the upper 'Irrawaddy Series' are hidden two Early Pleistocene sub-stages which as yet do not readily permit of the same detailed analysis. These earlier beds have yielded certain palæontological data which are likely to throw new light on their stratigraphic position.

\section{Palaeontological Aspects of the Pleistocene IN BURMa}

The 'Upper Irrawaddy' fauna has been known for some time, especially through studies by Noetling and Pilgrim, and lately Colbert has analysed it anew with the collection of Dr. B. Brown. The vertebrate fossils collected by us can only confirm the view that an 'Upper Siwalik' type of fauna is represented in these beds. In our material, forms such as Leptobos, Bubalus, Stegodon, primitive elephant and horse are most prominent, together with other types of lesser stratigraphic significance.

It is important to note that these beds have for the first time yielded both freshwater molluscs and plant remains. Their state of fossilization, as well as the type of freshwater fauna represented, clearly indicate an Early Pleistocene age for most of the 'Upper Irrawaddy' series. Moreover, the overlying terrace gravels contain a Middle Pleistocene type of fauna ( $\boldsymbol{E}$. namadicus, Bos cf. namadicus, Hippopotamus), reminiscent of the Narbada Pleistocene of peninsular India. Such a succession would be difficult to comprehend if the underlying beds were to represent the late Pliocene.

Of special interest was the discovery of fossiliferous fissure deposits in the Shan Plateau near Mogok. Except for a skull of Ailoropus, nothing was known of this fauna, which is likely to throw new light on former faunistic relationships of the Indian with the Chinese mammal world. The presence of Stegodon, Elephas namadicus, Bos, Rhinoceros, Cervus, Hystrix links this fauna with that typical for the limestone fissures found in the neighbouring provinces of China.

\section{Correlations with South China}

The conclusions arrived at by Teilhard de Chardin in regard to existing analogies between the late Cenozoic of Burma and China can only be mentioned very briefly in this report. Such analogies are striking "mainly $(a)$ in the late Pliocene lake deposits of the Shan Plateau; $(b)$ in the Early and Middle Pleistocene gravel formations; $(c)$ in the fissure deposits. All three are practically continuous between Eastern Burma and the Yangtse basin. They must therefore be contemporary and express the same series of diastrophic and climatic changes over the same geological unit". Hence the terraces of the Yangtse may be linked to those found in India and Burma, and "the possibilities of covering under a single stratigraphic and physiographic scheme the late Cenozoic history of the whole south and central Asiatic Mass becomes an assured possibility". 


\section{ARCHFOLOGY OF BURMA}

\section{By Hallam L. Movius}

At several localities in Upper Burma, fairly extensive sites yielding Lower Palæolithic tools were discovered. In all cases the implements are rolled and are associated with the main terrace $(T-3)$ gravels of the Irrawaddy Valley. This horizon may be assigned on palæontological grounds to the Middle Pleistocene. The principal sites are at Yenangyaung, Chauk and Nyaungoo (near Pagan), although further collecting was also done at Pakokku and at Pauk in the Yaw Valley. The implement types, which include chopping tools, crude scrapers, a few flake implements and cores, are made either of silicified tuff or fossil wood. Hand-axes are completely absent, a fact which seems to indicate a more definite association with an Eastern Asiatic focus than with an Indian one. Typologically, the closest analogies to the Lower Palæolithic of Burma are found at Patjitan in Java, but Dr. von Koenigswald's extensive collection from this latter region includes hand-axes, in addition to an abundance of Burmese forms. Thus at present the cultural affinities of the Burmese Palæolithic are not altogether clear, although the Java connexion cannot be denied. Perhaps both are derived from a common source somewhere in South China, or perhaps in Malaya.

Since an entirely new Lower Palæolithic complex is presented by the Burmese material, it has been named the 'Anyathian' after the coloquial Burmese for an Upper Burman (ān-ya-thā). The early Anyathian is represented by two phases-phase I from the basal cemented gravels of $T-3$, and phase 2 , which is derived from the overlying uncemented material. Only crude chopping tools, made of roughly tabular blocks of silicified wood, worked on the upper surface of one end, are found in the earliest phase. The implements are all heavily patinated and rolled. In phase 2 , however, the forms are more varied : several types of chopping tools, crude flake implements, and nuclei occur. The former include finely made core implements with alternately flaked cutting edges, while the latter are extremely coarse and are devoid of Levalloisean or Clactonian influences. In Burma, therefore, the chopper rather than the hand-axe is the type Lower Palæolithic implement.

The Late Anyathian is found unrolled on the surface of $T-3$ and slightly rolled in the Upper Pleistocene gravels of $T-4$. It seems to be essentially a development from the Early Anyathian, although the implement types are small and on the whole more specialized. They include many new forms - disk-shaped end-scrapers, sidescrapers, blades, and even steep scrapers of Upper Palæolithic type. Chopping tools of the Early
Anyathian are also present, which makes it difficult to determine whether this culture represents an innovation or an indigenous development brought under influence from an Upper Palæolithic centre outside the region.

No Mesolithic has yet been found in Burma although the cave region of the Southern Shan States was extensively explored. However, abundant Neolithic material was collected everywhere on the surface of the higher terraces, as well as in situ, associated with polished stone axes, at Minbu, and Kyaukpadaung. Pottery from the latter locality confirms the Neolithic dating of this complex, originally described by Noetling as "Eolithic", and more recently by Morris as "Upper Palæolithic".

Thus a chronological basis for the Burmese Stone Age has been established, and as Dr. de Terra points out, this archæological sequence is substantiated by stratigraphy. Burma has, therefore, added another link in our chain of knowledge concerning the development of early man in south-east Asia. One salient fact, however, which emerges from a preliminary study of the Anyathian, is the absence of influence from southern India. This is significant in the light of Dr. von Koenigswald's discoveries in Java, for if the culture of Patjitan is connected with India, traces of this connexion must inevitably exist in Burma. However, with the exception of the Javanese hand-axes, the Patjitanian and the Anyathian are almost identical. These facts, therefore, suggest that we are dealing with a new centre of Lower Palæolithic development in the Far East to which the orthodox European classification cannot be applied.

\section{ExCURSION TO JAVA}

Our field season in Burma closed at the end of March, when all members of the expedition proceeded to Java. Here we visited, under the guidance of Dr. von Koenigswald, the most important places where either fossil man or Old Stone Age cultures had in recent years been discovered. It is impossible to do full justice here to the truly remarkable wealth of information which Java holds in regard to Quaternary geology and early man.

Especially interesting to us was the Solo Valley with its terraces containing Palæolithic industries and the skulls of Homo neanderthalensis soløensis Oppenoorth. One cannot help but feel that a physiographic survey of this region will furnish a key to a more detailed stratigraphy which so far has been founded mainly on palæontological data. Here it became evident that the Quaternary of Java differs in many respects from that found in continental Asia; for one thing, volcanism has here introduced processes of sedimentation the periodic 
character of which is not readily recognized. Also, the climatic records of the humid tropics differ altogether from those found in more arid latitudes, and the effect upon fauna and sediments is such as to make direct correlations with the Quaternary of the Asiatic mainland less readily available than was at first anticipated.

The new site of the Pithecanthropus skull and mandible near Sangiran, north of Solo, assures beyond doubt the Middle Pleistocene age of this fossil. Its stratigraphic location was in the lower portion of the 'Trinil beds', which are here overlain by some $150 \mathrm{ft}$. of Middle and Upper Pleistocene fossiliferous strata, all of which are clearly exposed in one section. Especially clear is the position of the infant skull of Homo modjokertensis v. Koenigswald, near Modjokerto in eastern Java. Despite the relatively shallow depth at which the skull was discovered ( $3 \mathrm{ft}$. ), it was evident that in the absence of soils and terraces, nothing could have obscured the true location and stratigraphy of this fossil. Its age, according to von Koenigswald, is Lower Pleistocene because of its association with certain mammals, such as Hippopotamus antiquus and Cervus zwaani, as appear to be ancestral to others found in the Trinil fauna.

In concluding this report, I wish to express our sincerest appreciation for the financial support which the American Philosophical Society, Harvard University and the Carnegie Institution gave to this undertaking. We also wish to thank the Director of the Geological Survey of India, and the members of the Geological Department of Burma and our colleagues in Java for the friendly co-operation extended to us.

\section{International Committee on Social Relations of Science}

THE Committee on Science and its Social 1 Relations (C.S.S.R.), instituted by the International Council of Scientific Unions, in May of last year, held its second meeting in Paris this year, when a number of organizational questions connected with the work undertaken were discussed. From a report prepared by the secretary the following points may be mentioned:

As stated already (Nature, 140, 983; 1937. 141,723 ; 1938), the main work of the C.S.S.R. for the present is to collect materials for the preparation of a report and of bibliographies on the social relations of science, to be presented at the next meeting of the International Council in 1940, and thereafter, it is hoped, to be printed for wide circulation. For the execution of this plan, the C.S.S.R. has applied to the national academies, or other nationally representative bodies of various countries, and to a number of international scientific organizations, with the request to assist it in its task by supplying information, and by appointing correspondents who may gather around themselves other men of science interested in the work of the C.S.S.R., so as to form local or special groups co-operating with the latter. The Royal Society of London has nominated Prof. F. E. Weiss as its correspondent, and a subcommittee, with members for physics, chemistry, engineering and, if possible, also for medicine and for some other branches of science, is being formed.

To guide correspondents in furnishing their communications to the C.S.S.R., it was proposed to draw up questionnaires, indicating the points which should be judged to come within the scope of the inquiry. The preparation of these ques- tionnaires was a kind of experiment, as in a way they should form a programme for analysing the manifold influences that science and human society exert upon each other. Various points of view presented themselves, according to which topics might be classified; on one hand, attention should be given to the influence on social relations emanating from the application of a number of definite recent scientific discoveries ; on the other, the influence of science on the outlook of men and women should be considered. The relation between certain subjects and the life of human society further could be investigated according to national points of view, or from that of the various domains of science themselves.

It was decided, therefore, in the first place to draw up a 'general questionnaire', intended as a guide for the use of correspondents of the nationally representative scientific organizations of the various countries. The subjects listed in this questionnaire have been grouped under three headings, as follows : (1) the meaning of scientific research for the development of our world picture - to be understood not only in the philosophical sense, but also in the sense of the set of ideas with which the public (in its various forms of appearance) is operating ; (2) the influence of the applications of scientific work upon human society, the transformations that are induced by them and the adaptations which are required in consequence; (3) reactions of human society upon scientific work.

In connexion with the experimental character of the work, it may very well appear that other subjects besides those listed will have to be introduced, or that various questions should be framed 